\title{
Kaji Terap Pengaruh Penambahan Probiotik pada Pakan Komersil Terhadap Efisiensi Produksi Ikan Patin (Pangasius sp) di Kabupaten Jembrana
}

\author{
[Study Application the Effect Probiotic Addition in Commercial Feed on \\ Efficiency of Catfish (Pangasius sp) Production \\ In Jembrana Regency]
}

\author{
I Made Sedana ${ }^{1}$, I Ketut Sumadana ${ }^{2}$ \\ ${ }^{1}$ Penyuluh Perikanan Madya, Dinas Perhubungan Kelautan dan Perikanan Kabupaten Jembrana \\ Satminkal Balai Besar Riset Budidaya Laut dan Penyuluhan Perikanan \\ ${ }^{2}$ Banjar Dinas Gondol, Desa Penyambangan Kecamatan Gerokgak, Kabupaten Buleleng Bali (81153)
}

\begin{abstract}
Abstrak
Penelitian ini bertujuan untuk mengetahui pengaruh penambahan probiotik pada pakan komersial terhadap efisiensi pemanfaatan pakan (EPP), rasio konversi pakan (FCR), rasio efisiensi protein (PER), dan hasil produksi akhir ikan patin di Kabupaten Jembrana. Ikan uji yang digunakan adalah ikan patin (Pengasius sp.) dengan ukuran $3-5 \mathrm{~cm}$. Penelitian dilaksanakan di kolam milik Balai Benih Ikan Tegak Gede UPTD Dinas Perhubungan Kelautan dan Perikanan Kabupaten Jembrana. Metodologi penilitian adalah metode kaji lapang dengan membandingkan dua perlakuan yang berbeda dengan tiga ulangan selama satu periode pemebesaran ikan patin. Metode analisis data menggunakan analisa deskriftif analitik. Data yang diamati meliputi EPP, FCR, PER, dan hasil produksi akhir ikan patin. Hasil penelitian menunjukkan bahwa penambahan probiotik pada pakan komersil berpengaruh nyata $(P<0,05)$ terhadap EPP, RGR, FCR, PER, dan Hasil Produksi Ikan Akhir. Hasil penelitian juga menujukan korelasi yang sempuran dan positif antara EPP dengan Hasil Produksi sehingga meningkatkan efisiensi produksi ikan.
\end{abstract}

Kata Kunci: efisiensi; EPP; FCR; pakan; patin; PER; probiotik

\section{Abstract}

This study aims to determine the effect of adding probiotics in commercial feed to the EPP, FCR, PER, and efficiency of catfish production in Jembrana Regency. The test fish used was catfish (Pangaius $s p$ ) With a size of $3 \mathrm{~cm}-5 \mathrm{~cm}$, the study was carried out in a pond belonging to the UPTD BBI Tegak gede Jembrana Regency. The research methodology is a field study method by comparing two different treatments with three replications during one period of catfish enlargement. The data analysis method uses descriptive analytical analysis. Data observed included EPP, FCR, PER, and final catfish production. The results showed that the addition of probiotics in commercial food had a significant effect $(P<0.05)$ on EPP, RGR, FCR, PER, and Final Fish Production Results. In the study also addressed an intense and positive correlation between EPP and Production Results so as to increase the efficiency of fish production.

Keywords: catfish; efficeincy; EPP; FCR; feed; probiotics; PER

Penulis Korespondensi

I Made Sedana | imade.sedana@yahoo.co.id 


\section{PENDAHULUAN}

Ikan patin (Pangasius sp.) merupakan salah satu ikan perairan Indonesia yang telah berhasil didomestikasi dan dibudidayakan secara semi intensif dan intensif dengan padat penebaran tinggi dan penggunaan air yang minimal (Suresh dan Lin 1992 dalam Prabowo 2000). Dewasa ini permintaan ikan patin khususnya di Provinsi Bali relatif meningkat, terutama untuk konsumsi dan kolam pemancingan. Dalam kegiatan budidaya ikan air tawar khususnya ikan patin, pengeluaran terbesar adalah pengadaan pakan. Meningkatnya harga pakan pabrikan semakin menjadi masalah bagi kegiatan usaha budidaya ikan air tawar khususnya ikan patin di Kabupaten. Jembrana.

Kebutuhan pakan dalam budidaya ikan air tawar, dapat menghabiskan 60 $80 \%$ biaya produksi (Hadadi et al. 2009). Tingginya harga pakan dan kualitas nutrisi merupakan hal yang harus benarbenar diperhatikan dalam proses budidaya. Kandungan nutrisi pakan merupakan faktor utama tercapainya pertumbuhan ikan yang dibudidayakan. Kemampuan ikan untuk mencerna pakan yang dikonsumsi tergantung pada enzim yang terdapat di dalam saluran pencernaan ikan yang bereaksi dengan substrat di dalam saluran pencernaan ikan. Berdasarkan hal tersebut, dibutuhkan bahan tambahan, diantaranya dari jenis probiotik yang dapat meningkatkan efisiensi pemanfaatan pakan.

Probiotik merupakan feed additive (bahan tambahan) yang mengandung sejumlah mikroba yang memberikan efek menguntungkan kesehatan ikan, karena dapat memperbaiki keseimbangan mikroflora intestinal, sehingga dapat memberikan keuntungan berupa perlindungan, proteksi penyakit dan perbaikan daya cerna pakan. Enzim yang dihasilkan oleh mikroba yang terdapat dalam probiotik berupa protease, lipase dan amilase (Fardiaz dalam Setiawati et al. 2013). Enzim tersebut menghidrolisis molekul komplek seperti memecah karbohidrat, protein dan lemak menjadi molekul yang lebih sederhana sehingga mempermudah proses pencernaan dan menyerap nutrien dalam saluran pencernaan ikan (Putra 2014). Tujuan dari penelitian ini dilakukan adalah untuk mengetahui pengaruh penambahan probiotik pada pakan pabrikan terhadap efisiensi pemanfaatan pakan (EPP), rasio konversi pakan (FCR), rasio efisiensi protein (PER), dan hasil produksi akhir ikan patin ikan patin di wilayah Kabupatan Jembrana. 


\section{BAHAN DAN METODE}

\section{Waktu dan Tempat}

Penelitian ini dilaksanakan di Balai Benih Ikan Tegak Gede, Desa Yehembang Kangin, Kecamatan Mendoyo, Kabupaten Jembrana Bali dan dilaksanakan selama 6 Bulan dari bulan Juni - November 2019.

\section{Alat dan Bahan Penelitian}

Alat - alat yang digunakan adalah enam unit kolam dengan luas rata - rata kolam $90 \mathrm{~m}^{2}$, dan peralatan sampling. Bahan - bahan yang digunakan adalah benih ikan patin ukuran $3-5 \mathrm{~cm} / \mathrm{ekor}$, probiotik dan pakan pabrikan.

\section{Metode}

Penelitian ini dilakukan dengan menguji dua perlakuan dengan tiga kali ulangan. P0 adalah perlakuan ikan patin yang diberi pakan komersial tanpa penambahan probitik. Sedangkan P1 adalah dengan pemberian ikan patin pakan pbarikan dengan penambahan probiotik.

\section{Prosedur Penelitian}

Prosedur awal penelitian, adalah persiapan kolam serta adaptasi benih ikan uji. Tahap berikutnya adalah pelaksanaan penelitian. Selama penelitian metode pemberian pakan ikan yang diberikan berupa pellet komersial dengan frekuensi pemberian pakan 3 kali sehari. Dalam rentang waktu pukul 08.00, 12.00, dan 16.00 Wita dimana pemberian pakan secara ad libitum (pemberian pakan sampai kenyang) adapun indikator kenyang pada ikan adalah ikan tidak merespon lagi pakan yang diberikan.

Pakan pabrikan komersil yang digunakan dalam penelitian ini adalah $\mathrm{Hi}$ Pro-vit dengan kandungan protein 35\%. Probiotik ditambahkan kedalam pakan pabrikan dengan cara memfermentasi pakan tersebut dengan menambahkan $500 \mathrm{ml}$ probiotik ditambah $1 \mathrm{~kg}$ molase kemudian dicampurkan pada 1 zak (30 $\mathrm{Kg}$ ) pakan pabrikan dan di fermentasi selama dua hari.

\section{Analisis Data}

Metode penyajian data yang digunakan dalam penelitian ini adalah metode deskriptif analitik. Dimana deskripsi dilakukan melalui penyajian perbandingan perlakuan terhadap variable yang dinilai dalam bentuk tabel dan grafik. Untuk analisa pengaruh perlakuan terhadap produksi menggunakan uji t test, setelah didapat adanya pengaruh perbedaan perlakuan terhadap nilai variable yang diamati dilanjutkan dengan analisa korelasi Pearson untuk mengetahui adanya korelasi efisiensi penggunaan pakan ditambah probiotik terhadap produksi 
akhir ikan menggunakan perangkat lunak SPSS IBM 25.

\section{Parameter Penelitian}

\section{Efisiensi Pemanfatan Pakan}

Perhitungan efisiensi pemanfaatan pakan dengan menggunakan rumus menurut Zonneveld et al. (1991) sebagai berikut:

$$
E P P=\frac{W t-W o}{F} \times 100 \%
$$

Dimana: EPP: Efisiensi pemanfaatan pakan, Wt: bobot biomassa ikan pada akhir penelitian (g), Wo: bobot biomassa ikan pada awal penelitian (g), F : bobot pakan yang diberikan selama penelitian (g).

\section{Protein Efisiensi Ratio}

Perhitungan nilai protein efisiensi rasio menggunakan rumus menurut Tacon 1987 dalam Witjaksono (2009) sebagai berikut:

$$
\mathrm{PER}=\frac{\mathrm{Wt}-\mathrm{Wo}}{\mathrm{Pi}} \times 100 \%
$$

Dimana: PER $=$ Protein efisiensi rasio $(\%), \mathrm{Wt}=$ Berat akhir ikan selama penelitian (g), Wo = Berat awal ikan selama penelitian $(\mathrm{g}), \mathrm{Pi}=$ Berat pakan yang dikonsumsi $x \%$ protein pakan.

\section{Nilai Rasio Konversi Pakan}

Nilai rasio konversi pakan dapat dihitung menggunakan rumus menurut Effendie (2002).

$$
F C R=\frac{F}{(W t+D)-W o}
$$

dimana FCR = rasio konversi pakan; F = berat pakan yang dimakan $(\mathrm{g})$; Wt = biomassa ikan pada akhir pemeliharaan (g); $\mathrm{D}=$ bobot ikan yang mati (g); dan Wo = biomassa pada awal pemeliharaan $(\mathrm{g})$.

\section{HASIL DAN PEMBAHASAN}

Hasil

Dari kegiatan penelitian diperoleh data hasil produksi, FCR, EPP (\%) serta PER (\%) benih patin sebagaimana ditampilkan dalam Tabel 1, 2, 3, 4 serta Gambar 1, 2, 3, 4.

Tabel 1. Hasil Produksi/Perlakuan

\begin{tabular}{ccccc}
\hline Kolam & Jenis Perlakuan & $\begin{array}{c}\text { Jumlah } \\
\text { Pakan }(\mathbf{K g})\end{array}$ & $\begin{array}{c}\text { Berat } \\
\text { lkan Awal } \\
(\text { Kg) }\end{array}$ & $\begin{array}{c}\text { Produksi Ikan } \\
\mathbf{( K g )}\end{array}$ \\
\hline A1 & Po & 330 & 5 & 259 \\
A2 & Po & 330 & 5 & 260 \\
A3 & Po & 330 & 5 & 258 \\
A4 & P1 & 330 & 5 & 320 \\
A5 & P1 & 330 & 5 & 325 \\
A6 & P1 & 330 & 5 & 320 \\
\hline
\end{tabular}


Tabel 2. Pengamatan Variabel

\begin{tabular}{ccccc}
\hline Kolam & Jenis Perlakuan & FCR & EPP (\%) & PER (\%) \\
\hline A1 & Po & 1.30 & 76.97 & 26.939 \\
A2 & Po & 1.29 & 77.27 & 27.045 \\
A3 & Po & 1.30 & 76.67 & 26.833 \\
A4 & P1 & 1.05 & 95.45 & 33.409 \\
A5 & P1 & 1.03 & 96.97 & 33.939 \\
A6 & P1 & 1.05 & 95.45 & 33.409 \\
\hline
\end{tabular}

Keterangan :

Po : Perlakuan pakan tanpa penambahan probitik

P1 : Perlakuan pakan dengan penambahan probiotik dan fermentasi

Tabel 3. Nilai One Way t test

\begin{tabular}{cccc}
\hline No & Variabel Di Uji & $\begin{array}{c}\text { Nilai } \boldsymbol{\alpha} \text { T Test }(2- \\
\text { Tailed) }\end{array}$ & Keterangan \\
\hline 1 & Hasil Produksi (kg) & 0.000 & $<0.05$ \\
2 & EPP (\%) & 0.000 & $<0.05$ \\
3 & PER (\%) & 0.000 & $<0.05$ \\
4 & FCR & 0.000 & $<0.05$ \\
Keterangan : Nilai sig 2-tailed $<0.05$ terdapat perbedaan nilai yang nyata dari setiap perlakuan \\
\hline
\end{tabular}

Tabel 4. Hasil Nilai Korelasi Pearson

\begin{tabular}{l|l|c|c}
\hline \multicolumn{4}{c}{ Correlations } \\
\hline \multicolumn{2}{l}{} & Nilai EPP (\%) & $\begin{array}{c}\text { Hasil Produksi } \\
\text { Patin (Kg) }\end{array}$ \\
\hline Nilai EPP (\%) & Pearson Correlation & 1 & $1.000^{* *}$ \\
& Sig. (2-tailed) & 6 & .000 \\
Hasil Produksi Patin (Kg) & N & $1.000^{* *}$ & 6 \\
& Pearson Correlation & .000 & 1 \\
& Sig. (2-tailed) & 6 & 6 \\
\hline
\end{tabular}

${ }^{* \star}$. Correlation is significant at the 0.01 level (2-tailed). 


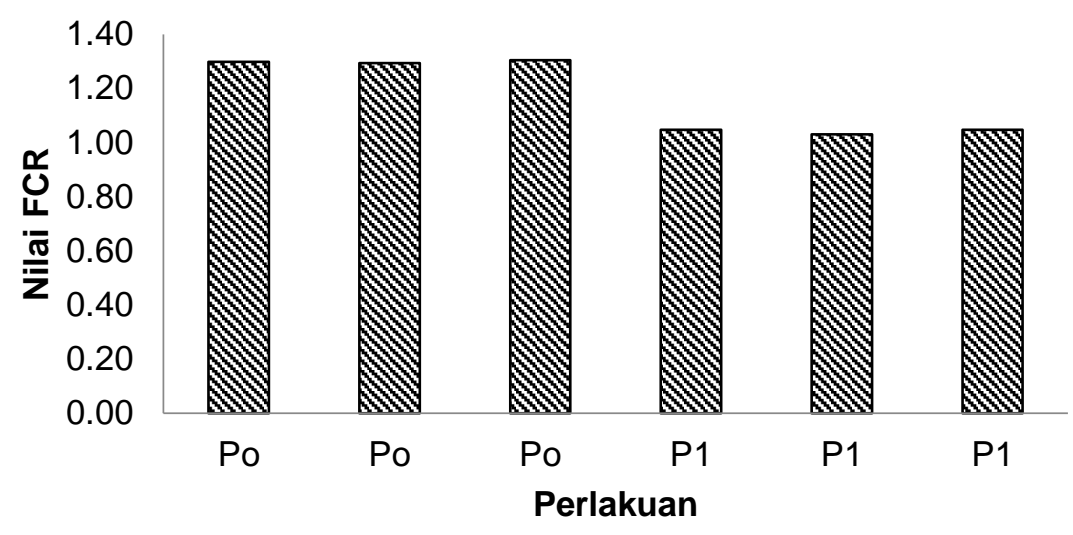

Gambar 1. Grafik Nilai Rasio Konversi Pakan

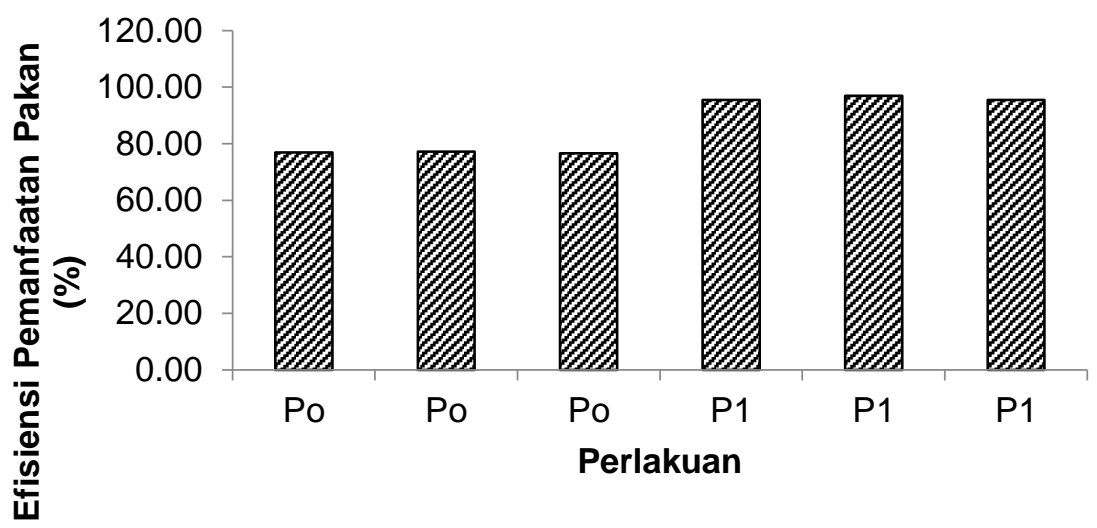

Gambar 2. Grafik Efisiensi Pemanfaatan Pakan

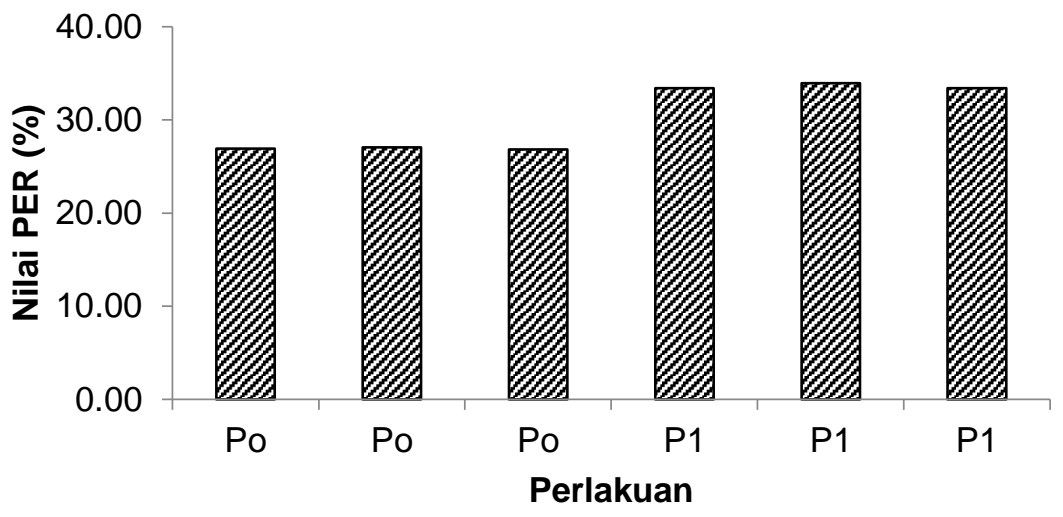

Gambar 3. Grafik Protein Efisiensi Ratio 


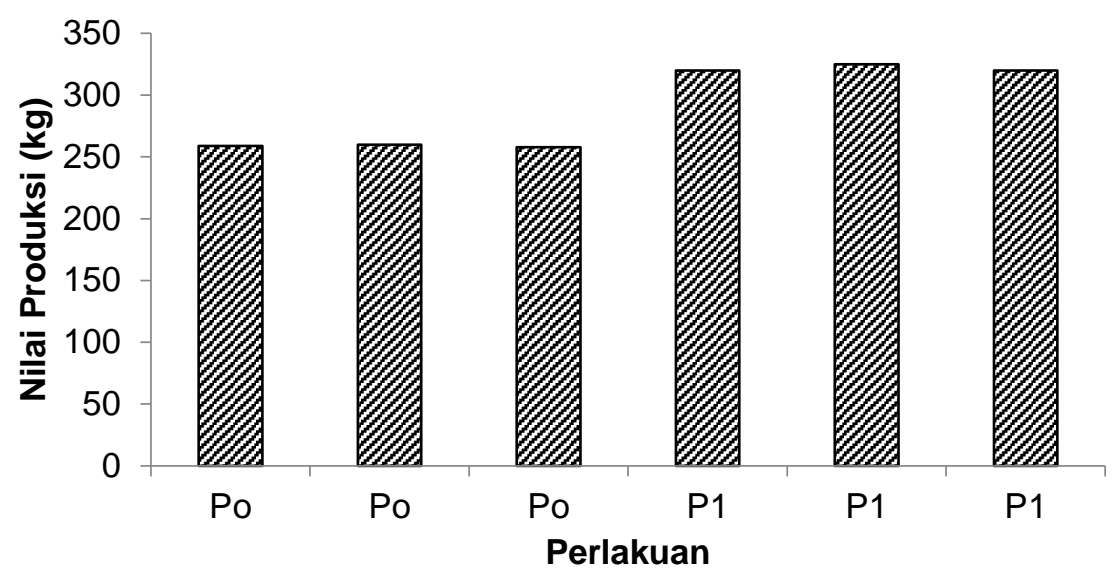

Gambar 4. Grafik Hasil Produksi Akhir Ikan Patin

\section{Pembahasan}

\section{Efisiensi Pemanfaatan Pakan (EPP)}

Berdasarkan data efisiensi pemanfaatan pakan ikan patin (Pangaius $s p)$ yang ditambahkan probiotik dengan tidak (Tabel 2), P1 menunjukkan nilai EPP antara 95\% - 97\%. Sedangkan nilai P0 menunjukkan nilai EPP antara $76 \%$ $78 \%$. Hasil penelitian ini menunjukkan bahwa penambahan probiotik pada pakan mampu meningkatkan efisiensi pemanfaatan pakan ikan patin sebesar 19\% dibandingkan tanpa pemberian probiotik. Hasil analisis t test pada tabel 3 menunjukkan bahwa penambahan probiotik dalam pakan komersil berpengaruh nyata $(P<0,05)$ terhadap efisiensi pemanfaatan pakan pada ikan patin (Pangasius Sp).

Menurut Kennedy et al. (1998) bakteri Bacillus sp. mampu mengurangi jumlah bakteri patogen dalam saluran pencernaan dan meningkatkan absorpsi pakan melalui peningkatan konsentrasi enzim protease pada saluran pencernaan, dimana enzim protease merupakan biokatalisator untuk reaksireaksi pemecah protein. Hartati dan Srihartati dan Sukirno (2003) menyatakan bahwa kecernaan berbanding lurus dengan efisiensi pemanfaatan pakan, sehingga apabila daya cerna pada ikan tersebut tinggi, maka nilai efisiensi pemanfaatan pakannya juga tinggi.

Menurut Irianto et al. (2003) bakteri dalam saluran pencernaan mampu menghasilkan enzim-enzim pencernaan seperti protease dan amilase. Dengan penambahan probiotik pada pakan komersial meningkatkan jumlah enzim yang dieksresikan sehingga tingkat kecernaan pakan ikan juga meningkat. Adanya penambahan probiotik pada pakan komersial menunjukkan bahwa ikan dapat memanfaatkan pakan yang 
diberikan secara optimal, sehingga pakan tersebut terserap kedalam tubuh melalui peredaran darah dan mengubah pakan menjadi daging.

\section{Rasio Efisiensi Protein (PER)}

Berdasakan data hasil penelitian (Tabel 2 dan Gambar 3), nilai PER ikan patin dengan perlakuan penambahan probiotik (P1) menunjukkan nilai antara 33.4 - 33.94\%. Sedangkan nilai PER ikan patin tanpa penambahan probiotik (Po) menunjukkan nilai antara 26.33 27.04\%. Menurut Stickney (1979) rasio efisiensi protein berfungsi untuk mengetahui jumlah protein yang terserap dalam tubuh ikan dan digunakan untuk pertumbuhan. Secara rata - rata pemberian pakan ikan patin dengan penambahan probiotik pada pakan komersial meningkatkan efisiensi penyerapan protein sebesar $6.65 \%$. Menurut Handayani et al. (2000) jumlah bakteri pengurai yang termakan akan membantu proses pencernaan dalam saluran pencernaan ikan. Hal ini dikarenakan bakteri ini mampu memproduksi enzim protease, amilase serta lipase dan meningkatkan keseimbangan bakteri dalam saluran pencernaan.

Berdasarkan analisa $\mathrm{t}$ test (one way $t$ test) menggunakan program SPSS IBM 25 didapat adanya pengaruh nyata dari perlakuan terhadap nilai PER
$(\mathrm{P}<0.05)$. Nilai $\mathrm{PER}$ pada perlakuan $\mathrm{P} 1$ menunjukan angka yang tertinggi. Hal ini diduga bakteri yang terkandung dalam probiotik tersebut mampu menghasilkan enzim-enzim yang dapat membantu ikan untuk mencerna protein lebih baik. Menurut Ramadhana et al. (2012) penambahan probiotik pada pakan dapat meningkatkan aktifitas enzim protease yang bertugas memecah protein menjadi asam amino, sehingga lebih mudah untuk diserap dan akhirnya jumlah protein yang disimpan dalam tubuh akan lebih besar.

Menurut Suprayudi et al. (2012) penambahan probiotik pada pakan dapat meningkatkan kecernaan protein hal ini disebabkan karena kandungan bakteri menguntungkan yang mampu menghasilkan enzim-enzim yang dapat membantu ikan untuk mencerna protein dalam protein. Bakteri yang terkandung dalam probiotik mampu meningkatkan kecernaan ikan dengan cara mengubah senyawa kompleks menjadi senyawa yang lebih sederahana. Noviana (2014) menyatakan bahwa pemberian probiotik yang mengandung bakteri Lactobacillius, Actinomycetes sp., dan Saccharmyces cerevisiae dalam pakan dimaksudkan untuk meningkatkan daya cerna ikan terhadap pakan dengan meningkatkan enzim pencernaan yang dapat menghidrolisis protein menjadi senyawa lebih sederhana sehingga mudah 
diserap dan digunakan sebagai deposit untuk pertumbuhan. Sedangkan menurut Anggriani dan Taofiqurohman (2012) bakteri Bacillus sp. berperan dalam menguraikan protein menjadi asam amino. Asam amino ini kemudian digunakan bakteri untuk memperbanyak diri, sehingga dapat meningkatkan protein pakan dan menurunkan serat kasar, sehingga mampu meningkatkan protein dan karbohidrat dalam pakan.

\section{Rasio Konversi Pakan (FCR)}

Berdasarkan data hasil penelitian ( Tabel 2 dan gambar 1 ), nilai FCR tertinggi terdapat pada ikan patin dengan perlakuan Po dengan kisaran nilai 1.29 1.30. Sedangkan nilai FCR terendah terdapat pada ikan patin dengan perlakuan P1 yang menunjukkan nilai antara $1.03-1.05$. Menurut Stickney (1979) rasio konversi pakan merupakan indeks dari pemanfaatan total pakan untuk pertumbuhan atau jumlah gram pakan yang diperlukan ikan untuk menghasilkan $1 \mathrm{~g}$ berat basah ikan. Sehingga semakin kecil nilai FCR maka semakin baik dan menguntungkan kegiatan usaha budidaya ikan khususnya patin. Penambahan probiotik pada pakan komersil terhadap produksi ikan patin mampu menurunkan nilai FCR sebesar 0.26 dibandingkan tanpa penambahan probiotik pada pakan komersil.
Berdasarkan hasil t test ( tabel 3 ), menunjukkan adanya pengaruh nyata antar perlakuan terhadap nilai FCR $(P<0.05)$, yang berarti penambahan probiotik dapat menurunkan nilai FCR. Hal ini sesuai dengan pendapat Stickney (1979) bahwa nilai rasio konversi pakan berhubungan erat dengan kualitas pakan. Semakin rendah nilai konversi pakan maka akan semakin efisien ikan dalam memanfaatkan pakan yang dikonsumsinya untuk pertumbuhan, sehingga bobot tubuh ikan akan meningkat dikarenakan pakan dapat dicerna secara optimal.

\section{Efisiensi Hasil Produksi Ikan Patin (Pangaius sp)}

Berdasarkan hasil penelitian ( tabel 1 dan gambar 4 ), nilai produksi ikan patin tertinggi diperoleh pada perlakuan P1 dengan nilai 320 - $325 \mathrm{Kg}$. Sedangkan hasil produksi pada perlakuan $\mathrm{Po}$ berkisar antara $258-260 \mathrm{Kg}$. Berdasarkan hal tersebut maka penambahan probiotik pada pakan komersil mampu meningkatkan produksi sebesar $62.67 \mathrm{Kg}$. Kondisi Ini diduga karena tingkat efisiensi pemanfaatan pakan yang tinggi pada perlakuan penambahan probitik pada pakan ikan. Lactobacillus akan mengubah karbohidrat menjadi asam laktat, kemudian asam laktat dapat menciptakan suasana $\mathrm{pH}$ yang lebih rendah. Dalam keadaan asam, 
Lactobacillus memiliki kemampuan untuk menghambat bakteri patogen dan bakteri pembusuk (Delgado et al. 2001 dalam Arief et al. 2014).

Berdasarkan hasil penelitian (tabel $3)$, terlihat adanya pengaruh nyata antar perlakuan terhadap hasil produksi akhir ikan patin $(\mathrm{P}<0.05)$. Adanya perbedaan pengaruh nyata dari masing - masing perlakuan terhadap produksi, menyebabkan perlu dilakukan uji lanjutan untuk memberikan gambaran yang lebih utuh. Hasil uji korelasi pearson ( tabel 4 ), menunjukan adanya nilai korelasi yang signifikan antara hasil produksi ikan patin dengan EPP $(\mathrm{P}<0.05)$. Dapat pula dilihat adanya korelasi atau hubungan yang sempurna dan postif antara hasil produksi dan EPP (Pearson Correlation =1). Hal ini sejalan dengan pendapat Djajasewaka (1986) dalam Jariyah et al (2013) bahwa nilai efisiensi akan berbanding terbalik dengan konversi pakan dan berbanding lurus dengan pertambahan berat tubuh ikan, sehingga semakin tinggi nilai efisiensi pakan maka nilai konversi pakan semakin rendah. Adanya penambahan probiotik pada pakan komersial dalam upaya budidaya pembesaran ikan patin meningkatkan efisiensi produksi ikan yang dibudidayakan.

\section{SIMPULAN}

Simpulan dari hasil penelitian ini adalah sebagai berikut :

1. Adanya pengaruh nyata penambahan probiotik pada pakan ikan patin komersil $(\mathrm{P}<0.05)$ terhadap EPP, PER, FCR, dan Hasil Produksi Ikan Patin dalam upaya budidaya pembesaran ikan patin;

2. Adanya korelasi yang sempurna antara EPP dan hasil produksi (Pearson Correlation = 1$)$, menunjukkan pengaruh dari penambahan probiotik pada pakan komersil dalam upaya pembesaran ikan patin.

\section{DAFTAR PUSTAKA}

Anggriani R, Taofiqurohman A. 2012. Efektivitas Penambahan Bacillus SP. Hasil Isolasi Dari Saluran Pencernaan Ikan Patin Pada Pakan Komersial Terhadap Kelangsungan Hidup Dan Pertumbuhan Benih Ikan Nila Merah (Oreochromis Niloticus). J. Perikan. Kelaut. 3(3): 
Arief M, Fitriani N, Subekti S. 2014. Pengaruh Pemberian Probiotik Berbeda pada Pakan Komersial terhadap Pertumbuhan Dan Efisiensi Pakan Ikan Lele Sangkuriang (Clarias Sp.)[The Present Effect Of Different Probiotics On Commercial Feed Towards Growth And Feed Efficiency Of Sangkuriang Catfish . J. IIm. Perikan. dan Kelaut. 6(1):49-54.

Effendie MI. 2002. Biologi Perikanan (Edisi Revisi). Yogyakarta (ID): Yayasan Pustaka Nusantara.

Hadadi A, Herry KT, Wibowo E, Pramono A, Surahman RE. 2009. Aplikasi Pemberian Maggot Sebagai Sumber Protein Dalam Pakan Ikan Lele Sangkuriang (Clarias Sp) Dan Gurame (Osphronemus Gouramy Lac). Sukabumi (ID).

Handayani R, Kokarkin C, Astute SM. 2000. Pemanfaatan Enzim Bakteri Remedian Pada Pemeliharaan Larva Udang Windu. Jepara (ID).

Irianto A, Robertson PAW, Austin B. 2003. Oral administration of formalin-inactivated cells of Aeromonas hydrophila A3-51 controls infection by atypical $A$. salmonicida in goldfish, Carassius auratus (L.). J. Fish Dis. 26(2):117120. doi:10.1046/j.1365-

2761.2003.00439.x.
Kennedy SB, Tucker Jr JW, Neidig CL, Vermeer GK, Cooper VR, Jarrell JL, Sennett DG. 1998. Bacterial management strategies for stock enhancement of warmwater marine fish: a case study with common snook(Centropomus undecimalis). Bull. Mar. Sci. 62(2):573-588.

Noviana P. 2014. Pengaruh Pemberian Probiotik Dalam Pakan Buatan Terhadap Tingkat Konsumsi Pakan Dan Pertumbuhan Benih Ikan Nila (Oreochromis Niloticus). J. Aquac. Manag. Technol. 3(4):183-190.

Prabowo H. 2000. Pengaruh padat penebaran terhadap pertumbuhan dan kelangsungan hidup ikan lele dumbo (Clarias sp) pada pendederan menggunakan sistem resirkulasi dengan debit air $22 \mathrm{~L}$ /menit/m3 [Skripsi]. Institut Pertanian Bogor.

Putra AM. 2014. Pertumbuhan Ikan Patin (Pangasiussp.) yang dipelihara dalam Sistem Resirkulasi [skripsi]. Universitas Sumatera Utara.

Ramadhana S, Fauzana NA, Ansyari P. 2012. Pemberian Pakan Komersil dengan Penambahan Probiotik yang Mengandung Lactobacillus sp. terhadap Kecernaan dan Pertumbuhan Ikan Nila (Oreochromis niloticus). Fish Sci. 2(4):178-187. 
Setiawati JE, Adiputra YT, Hudaidah S. 2013. Pengaruh penambahan probiotik pada pakan dengan dosis berbeda terhadap pertumbuhan, kelulushidupan, efisiensi pakan dan retensi protein ikan patin (Pangasius hypophthalmus). EJurnal Rekayasa dan Teknol. Budid. Perair. 1(2):151-162.

Srihartati, Sukirno. 2003. Analisis Kelayakan Pembuatan Pakan dan Budidaya Ikan Gurame di Desa Glempang Kecamatan Maos Kabupaten Cilacap. In Pemaparan Hasil Litbang, Bandung (ID): Pusat Penelitian Informatika - LIPI, hal.

Stickney RR. 1979. Principles Of Warmwater Aquaculture. John Wiley \& Sons.
Suprayudi MA, Harianto D, Jusadi D. 2012. Kecernaan pakan dan pertumbuhan udang putih Litopenaeus vannamei diberi pakan mengandung enzim fitase berbeda The effect of phytase levels in the diet on the digestibility and growth performance of white shrimp Litopenaeus vannamei. J. Akuakultur Indones. 11(2):103108.

Witjaksono A. 2009. Kinerja produksi pendederan lele sangkuriang (clarias sp.) melalui penerapan teknologi ketinggian media air 15 $\mathrm{cm}, 20 \mathrm{~cm}, 25 \mathrm{~cm}$, dan $30 \mathrm{~cm}$. Institut Pertanian Bogor.

Zonneveld N, Huisman EA, Boon JH. 1991. Prinsip-prinsip budidaya ikan. Jakarta PT. Gramedia Utama Pustaka. 